\title{
HUBUNGAN TANGGAPAN DAN SIKAP WARGA KOTA MADIUN TERHADAP MEMBAYAR ZAKAT/ JIZYAH SEBAGAI SUMBER APBN/APBD
}

\author{
Siti Muhayati, Diana Ariswanti Triningtyas *) \\ Juli Muwarni **)
}

\begin{abstract}
Between Budget and Budget State Local Income in equality especially lower budget from the budget, and 50\%-60\% Budget spent for paying employees the reasons is the lack of participation of citizens to fund the management of the state by paying the zakat (Muslim) jizyah (non-Muslim). The purpose of this study was to determine the response and attitude of the towns people Madiun to pay Zakat/jizyah as a source of state budget/budget. This research was conducted in Madiun by taking a sample of three villages of nine districts. The method is quantitative with ex-post facto design, collection document and questionnaire data and data product moment correlation analysis ( $T$ test). Results zero hypothesisis accepted because $t_{0}(0.059)$ is smaller than $t_{t}(1.96)$ level significansi $5 \%$ or $1 \%(2.59)$, this shows that a person's response to the zakat/jizyah as a source of state budget/budgetis proportional. Or no difference in the attitude of paying zakat/jizyah, both of whichare clear about the function of zakat, is being, or less. Respondents who understand the positive response is proportional to attitudes, respondents were then negative response is proportional to the negative attitude; respondents were not sure what it is a very negative response is proportional to the extremely negative attitude or do not pay zakat.
\end{abstract}

Keywords: Respondents, attitudes, Zakat/Jizyah

* Siti Muhayati \& Diana Ariswanti Triningtyas adalah Dosen Program Studi Bimbingan dan Konseling Fakultas Ilmu Pendidikan IKIP PGRI MADIUN.

** Juli Muwarni adalah Dosen Program Studi Pendidikan Akuntansi Fakultas Pendidikan Ilmu Pengetahuan Sosial IKIP PGRI MADIUN. 


\section{PENDAHULUAN}

Antara Anggaran Pendapatan dan Anggaran Belanja Negara/Daerah ada ketimpangan terutama Anggaran Pendapatan lebih rendah dari Anggaran Belanja, dan 50\%-60\% Anggaran Belanja habis untuk menggaji pegawai, baik Pusat maupun Daerah. Hal ini salah satu penyebabnya adalah kurangnya peran serta warga negara untuk mendanai pengelolaan negara dengan membayar zakat (muslim) jizyah (non muslim). Oleh karena itu tujuan penelitian ini adalah untuk mengetahui tanggapan dan sikap warga Kota Madiun terhadap membayar zakat/ jizyah sebagai sumber APBN/APBD. Tercapai tujuan tersebut dengan mengadakan penelitian. Definisi istilah yang relevan dari penelitian ini adalah Tanggapan, Sikap, dan Zakat/ Jizyah. Manfaat dari penelitian ini adalah untuk mengembangkan hipotesa bahwa Tidak ada perbedaan antara Tanggapan dan Sikap membayar Zakat/ Jizyah.

\section{KAJIAN LITERATUR DAN PENGEMBANGAN HIPOTESIS}

a. Tinjauan Pustaka

Hasil Penelitian dan Artikel

Hasil penelitian Siti Muhayati (2013), meneliti tentang Tanggapan Narapidana Lembaga Pemasyarakatan Kota Madiun Pada Sanksi Hukum Pidana Islam Terhadap Sikap Taubatan Nashuha.

Artikel tentang Sistem Politik Dalam Islam oleh Amirul Amin, 6 September 2010 pukul 12:21 menjelaskan tentang para fuqaha Islam telah menggariskan sepuluh perkara penting sebagai tujuan sistem politik dan pemerintahan Islam. Salah satunya adalah mengendalikan urusan pengutipan cukai, zakat dan sedekah sebagaimana yang ditetapkan oleh syara'; mengatur anggaran belanja dan perbelanjaan daripada perbendaharaan negara agar tidak digunakan secara boros ataupun secara kikir. Dari penjelasan tersebut maka penulis tergerak untuk memasukan zakat sebagai sumber APBN/APBD.

Artikel tentang jizyah. Dalam artikel tersebut menjelaskan bahwa jizyah adalah mengeluarkan sebagian harta sesuai dengan jumlah, ukuran, dan waktu tertentu yang diberikan pada ulil amri sebagai jasa karena mereka telah di lindungi hak syar'i manusianya. Jizyah ini dibebankan pada non muslim yang berdomisili di negara Islam. Konteksnya warga muslim dan non muslim berdomisili di NKRI maka jizyah (non muslim) diqiyaskan dengan zakat (muslim), ya'ni keduanya mempunyai kewajiban yang sama untuk mendanai pengakuan, penghormatan dan perlindungan hak masing-masing mereka.

Artikel tentang Anggaran Pendapatan Belanja Negara. Dari Wikipedia bahasa Indonesia, ensiklopedia bebas. Anggaran Pendapatan dan Belanja Negara (APBN), adalah rencana keuangan tahunan pemerintahan negara Indonesia yang disetujui oleh Dewan Perwakilan Rakyat. APBN berisi daftar sistematis 
dan terperinci yang memuat rencana penerimaan dan pengeluaran negara selama satu tahun anggaran (1 Januari-31 Desember). APBN, perubahan APBN, dan pertanggungjawaban APBN setiap tahun ditetapkan dengan Undang-Undang. Pembahasan tentang APBN ini adalah Sumber penerimaan APBN. Penerimaan APBN diperoleh dari berbagai sumber yaitu, Penerimaan pajak yang meliputi: Pajak Penghasilan (PPh); Pajak Pertambahan Nilai (PPN); Pajak Bumi dan Bangunan (PBB); Bea Perolehan Hak atas Tanah dan Bangunan (BPHTB) \& Cukai); Pajak \& Cukai); Pajak lainnya seperti Pajak Perdagangan (bea masuk dan pajak/pungutan ekspor). Penerimaan Negara Bukan Pajak (PNBP) meliputi: Penerimaan dari sumber daya alam; Setoran Laba Badan Usaha Milik Negara (BUMN); Penerimaan bukan pajak lainnya. Adapun Belanja lainnya seperti Pajak Perdagangan (bea masuk dan pajak/pungutan ekspor). Penerimaan Negara Bukan Pajak (PNBP) meliputi: Penerimaan dari sumber daya alam; Setoran laba Badan Usaha Milik Negara (BUMN); Penerimaan bukan pajak lainnya. Adapun Belanja Negara terdiri atas dua jenis: Belanja Pemerintah Pusat, adalah belanja yang digunakan untuk membiayai kegiatan pembangunan Pemerintah Pusat, baik yang dilaksanakan di pusat maupun di daerah (dekonsentrasi dan tugas pembantuan). Belanja Pemerintah Pusat dapat dikelompokkan menjadi: Belanja Pegawai; Belanja Barang; Belanja Modal; Pembiayaan Bunga Utang; Subsidi BBM dan Subsidi Non-BBM; Belanja Hibah; Belanja Sosial (termasuk Penanggulangan Bencana). Belanja Daerah adalah belanja yang dibagi-bagi ke Pemerintah Daerah, untuk kemudian masuk dalam pendapatan $\underline{\text { APBD }}$ daerah yang bersangkutan. Belanja Pemerintah Daerah meliputi: Dana Bagi Hasil; Dana Alokasi Umum; Dana Alokasi Khusus; Dana Otonomi Khusus.

b. Konsepsi

Tanggapan

Zakat

Makna Zakat

Menurut Bahasa (lughat), zakat berarti: tumbuh; berkembang; kesuburan atau bertambah (HR. At-Tirmidzi) atau dapat pula berarti membersihkan atau mensucikan (QS. At-Taubah:10). Menurut Hukum Islam (istilah syara'), zakat adalah nama bagi suatu pengambilan tertentu dari harta yang tertentu, menurut sifat-sifat yang tertentu dan untuk diberikan kepada golongan tertentu (Al Mawardi dalam kitab Al Hawiy). 
Hukum Zakat

Zakat merupakan salah satu rukun Islam, dan menjadi salah satu unsur pokok bagi tegaknya syariat Islam. Oleh sebab itu hukum zakat adalah wajib (fardhu) atas setiap muslim yang telah memenuhi syarat-syarat tertentu.

Macam-macam Zakat

Zakat Nafs (jiwa), juga disebut zakat fitrah, Zakat Maal (harta).

Syarat-syarat Wajib Zakat

Muslim, Aqil, Baligh, Memiliki harta yang mencapai nishab (Al Faridy, Hasan Rifa'i, 1996)

Harta yang Wajib Zakat dan Kadarnya (Suratno, S.Ag.,)

Dalam menentukan yang dikenakan wajib zakat ini, ada empat hal yang harus diperhatikan, yaitu: 1) jenis-jenis harta yang dikenakan zakat (yang wajib dikeluarkan zakatnya); 2) besarnya jumlah harta benda yang dikenakan zakat tiap-tiap jenis tersebut (nishab); 3) besarnya pungutan yang dikenakan atas tiap jenisnya; 4) waktu-waktu pemungutan zakat.

Jenis-jenis harta yang wajib dikeluarkan zakatnya dan besar kadar masingmasing harta tersebut adalah sebagai berikut :

Emas dan Perak; Dasar hukum wajib zakat bagi harta yang berupa emas dan perak terdapat dalam QS At Taubah 34-35. Nishab untuk emas adalah 20 dinar, yaitu senilai dengan 85 gram emas murni. Sedangkan untuk perak adalah 200 dirham, yaitu senilai 672 gram perak, maka wajib zakat sebesar 2,5\%. Untuk emas dan perak simpanan yang masing-masing kurang dari senishab, tidak perlu dikumpulkan menjadi satu agar senishab yang kemudian di keluarkan zakatnya. Misalnya, seseorang yang memiliki simpanan emas sebesar 10 dinar dan perak 100 dirham maka keduanya tidak dikenakan zakat. Untuk segala macam jenis harta lain yang merupakan harta simpanan dan dapat dikategorikan dalam emas dan perak, seperti uang, tabungan, cek, saham, surat berharga dan lain-lain, maka nishab dan zakatnya sama dengan ketentuan emas dan perak. Jika seseorang memiliki bermacam-macam harta dan jumlahnya lebih besar atau sama dengan nishab emas dan perak maka telah terkena wajib zakat sebesar $2,5 \%$.

Harta Dagangan.

Dasar hukum wajib zakat terhadap barang dagangan adalah pada QS Al Baqoroh : 267. Dari ayat tersebut di atas menunjukan bahwa untuk barang dagangan termasuk dalam harta yang wajib dikeluarkan zakatnya. Sedangkan yang dimaksud dengan barang dagangan adalah semua yang diperuntukkan untuk diperjual-belikan dalam berbagai jenisnya, baik berupa barang seperti alat-alat, pakaian, makanan, perhiasan, dan lain-lain. Nishab barang dagangan adalah setara dengan nishab emas yaitu sebesar 20 dinar (85 gram emas murni) dan sudah berjalan satu tahun. 
Hasil Pertanian.

Dasar hukum wajib zakat untuk hasil pertanian adalah firman Allah dalam QS. Al An'am :141. Nishab harta pertanian adalah sebesar 5 wasaq atau setara dengan $750 \mathrm{~kg}$. Untuk hasil bumi yang berupa makanan pokok, seperti beras, jagung, gandum, dan lain-lain sebesar $750 \mathrm{~kg}$ dari hasil pertanian tersebut. Sedangkan untuk hasil pertanian selain makanan pokok, seperti sayur-mayur, buah-buahan, bunga, dan lain-lain, maka nishabnya disetarakan dengan harga nishab makanan pokok yang paling umum di daerah tersebut. Untuk hasil pertanian ini tidak ada haul, sehingga wajib dikeluarkan zakatnya setiap kali panen. Kadar zakat yang dikeluarkan untuk hasil pertanian yang di airi dengan air sungai, air hujan atau mata air adalah sebesar $10 \%$. Sedangkan apabila pengairannya memerlukan biaya tambahan, misalnya dengan disiram atau irigasi maka kadar zakatnya adalah $5 \%$.

Binatang Ternak.

Pada binatang ternak, nishab dan besarnya kadar zakat yang wajib dikeluarkan adalah berbeda-beda untuk setiap jenis binatang. Binatang yang lazim dikenakan zakat di Indonesia adalah, sapi, kerbau, kambing. Sedangkan untuk binatang jenis unggas, seperti ayam, itik, burung, dan sebagainya tidak dikenakan zakat kecuali jika dijadikan dagangan atau usaha peternakan.

Sapi/Kerbau.

Pada tabel berikut dapat dilihat lebih jelas lagi mengenai nishab dan besarnya kadar zakat sapi.

\begin{tabular}{|c|l|}
\hline Jumlah & \multicolumn{1}{|c|}{ Zakat } \\
\hline 30-39 ekor & 1 ekor sapi jantan/ betina tabi' \\
\hline 40-49 ekor & 1 ekor sapi betina mussinah \\
\hline $60-69$ ekor & 2 ekor sapi tabi' \\
\hline 70-79 ekor & 2 ekor sapi mussinah dan 1 ekor tabi' \\
\hline 80-89 ekor & 2 ekor sapi mussinah \\
\hline
\end{tabular}

Kambing. Untuk kambing/domba, maka nishabnya adalah 40 ekor. Unggas.

Nishab untuk binatang unggas ini berbeda dengan sapi atau kambing. Unggas yang terkena wajib zakat terbatas pada unggas yang diusahakan, misalnya peternakan. Nishabnya bukan berdasarkan jumlah melainkan disetarakan dengan nishab emas yaitu sebesar 20 dinar atau sama dengan 85 gram emas murni. Artinya adalah apabila seseorang beternak unggas dan pada akhir tahun telah mencapai nishab tersebut maka dikenai wajib zakat sebesar 2,5\%. Rikaz. Rikaz atau harta karun adalah semua harta yang ditemukan oleh seseorang dari dalam tanah atau pada tempat tertentu yang merupakan peninggalan dari orang-orang terdahulu. Apabila seorang muslim menemukan 
harta rikaz tersebut maka ia terkena wajib zakat sebesar seperlima dari jumlah harta yang ditemukan tersebut. Pada harta rikaz ini tidak ada ketentuan haul. Dasar hukum yang mewajibkan harta rikaz untuk dikenai zakat adalah hadist sebagai berikut : 'Dari Amru bin Syu'aib, dari ayahnya, dari datuknya, bahwa Rosulullah SAW pernah bersabda tentang simpanan yang didapati oleh seseorang pada suatu desa yang dihuni orang: Jika engkau dapatkannya pada suatu desa yang didiami orang maka umumkan ia. Dan jika engkau dapatkan pada suatu desa yang tidak dihuni orang, maka padanya dan pada rikaz itu seperlima,' '(HR. Ibnu Majah dengan sanad yang hasan).

Ma'adin dan kekayaan laut.

Harta ma'din adalah benda-benda yang terdapat dalam perut bumi dan memiliki nilai ekonomis, misalnya, emas, perak, timah, batu bara, minyak bumi, batu-batuan serta hasil tambang lainnya. Sedangkan kekayaan laut adalah segala sesuatu yang dieksplotasi manusia dari dasar laut, misalnya mutiara, ambar, dan lain-lainnya. Untuk kedua jenis harta ini, nishabnya adalah sebesar 20 dinar emas murni atau 85 gram emas murni dan kadarnya adalah sebesar 2,5\% tanpa perlu mencapai haul.

Hasil Profesi.

Zakat hasil profesi merupakan zakat yang dikeluarkan dari hasil usaha orangorang muslim yang memiliki keahlian dibidangnya masing-masing. Seperti, dokter, pengacara, dan berbagai profesi lainnya. Mengenai zakat terhadap hasil profesi, terdapat perbedaan pendapat antara para ulama. Karena memang tidak ada dalil khusus yang mewajibkan harta hasil profesi untuk dikenai zakat. Sedangkan para ulama yang berpendapat bahwa harta hasil profesi wajib zakat, berpegang pada firman Allah yang terdapat pada QS. Al Baqoroh :267. Apabila dilihat dari ayat diatas maka hasil profesi dapat dimasukkan sebagai harta yang wajib zakat. Para ulama yang cenderung memasukkan harta hasil profesi sebagai harta yang wajib zakat, memberikan gambaran perbandingan antara hasil yang diperoleh oleh seorang petani dengan hasil yang diperoleh oleh seorang pegawai. Saat ini dapat diketahui bahwa penghasilan seorang pegawai dapat lebih besar dari hasil seorang petani. Oleh karena itu, akan sangat sulit dimengerti apabila untuk seorang petani dikenai zakat sedangkan seorang pegawai tidak dikenakan zakatnya. Yang menjadi permasalahannya adalah berapa nishab untuk zakat hasil profesi ini karena tidak ditemukan dalil khusus yang mengaturnya. Para ulama menyamakan harta hasil profesi ini dengan harta simpanan, sehingga nishab bagi harta hasil profesi ini disamakan dengan nishab emas atau nishab uang. Yaitu, sebesar 20 dinar atau 85 gram emas murni dan kadar yang harus dikeluarkan sebesar $2,5 \%$, yang dikeluarkan setiap tahun. 
Saham dan Obligasi.

Saham adalah hak pemilikan tertentu atas kekayaan satu Perseroan Terbatas atau atas penunjukan atas saham tersebut. Sedangkan obligasi adalah perjanjian tertulis dari bank, perusahaan, atau pemerintah kepada seseorang (pembawanya) untuk melunasi sejumlah pinjaman dalam masa tertentu dan dengan bunga tertentu pula. Pada hakekatnya saham dan obligasi termasuk bentuk penyimpanan harta yang mempunyai potensi untuk berkembang. Sehingga dapat dikategorikan sebagai harta yang wajib dizakati, apabila telah mencapai nishabnya. Kadarnya adalah $2,5 \%$ dari nilai kumulatif riil bukan nilai nominal yang tertulis pada saham atau obligasi tersebut, dan zakat dibayarkan setiap tahun.

Undian atau Kuis Berhadiah.

Harta yang diperoleh dari hasil undian dan kuis berhadiah di identikkan dengan harta hasil temuan (rikaz). Oleh karena itu, kadar zakat yang harus dikeluarkan adalah sebesar 20\% dari harta yang diperoleh, tanpa syarat haul.

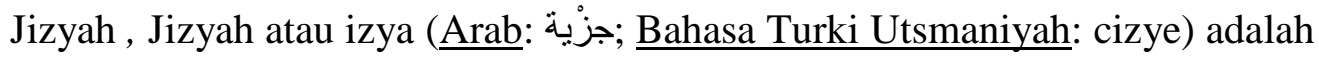
pajak per kapita yang diberikan pada penduduk non-Muslim pada suatu negara di bawah peraturan Islam. Istilah Arab jizyah ada pada Qur'an 9:29, tetapi Qur'an tidak men-spesifisikan jizyah sebagai pajak per kepala (Artikel ini diambil daribab Jihad buku The Religion of Islam yang telah diindonesiakan dengan judul Islamologi). Menurut penjelasan ulama, kata jizyah berarti pajak yang dipungut dari rakyat non Muslim merdeka dalam negara Islam, yang dengan pajak itu mereka mengesahkan perjanjian yang menjamin mereka mendapat perlindungan, atau suatu pajak yang dibayar oleh pemilik tanah. Kata jizyah berasal dari kata jaza artinya membalas jasa atau mengganti kerugian terhadap suatu perkara, atau terhadap perbuatan yang telah dilakukan. Pada zaman Khalifah 'Umar, jizyah dibayar perorangan atau kepala keluarga yang mampu, sedang tidak mampu tidak membayar jizyah seperti fakir miskin dalam Islam tidak membayar zakat.

Sikap

Sikap adalah suatu bentuk dari perasaan, yaitu perasaan mendukung atau memihak (favourable) maupun perasaan tidak mendukung (Unfavourable) pada suatu objek (Robert S F: 2012). Sikap adalah istilah yang mencerminkan senang, tidak senang atau perasaan biasa-biasa saja (netral) dari sesorang terhadap sesuatu. Sesuatu itu bisa benda, situasi, kejadian, orang-orang atau kelompok. Kalau yang timbul terhadap sesuatu itu adalah perasaan senang, maka disebut sikap positif, sedangkan kalau perasaan tidak senang, sikap negatif. Kalau tidak timbul perasaan apa-apa, berarti sikapnya netral (Sarwono, 2009).

Sikap dinyatakan dalam tiga komponen ABC, yaitu Affect 
Behaviour dan Cognition. Affect adalah perasaan yang timbul (senang, tak senang), Behaviour perilaku yang mengikuti perasaan itu (mendekat, menghindar), dan Cognition adalah penilaian terhadap sikap itu (bagus, tidak bagus) (Sarwono, 2009).

Menurut Robert S F (2012) komponen sikap adalah: 1). Komponen kognisi yang berhubungan dengan belief (kepercayaan atau keyakinan), ide, konsep; 2). Komponen afeksi yang berhubungan dengan kehidupan emosional seseorang; 3). Komponen kognisi yang merupakan kecenderungan bertingkah laku.

Faktor-faktor yang mempengaruhi pembentukan sikap meliputi: pengalaman pribadi, kebudayaan, orang lain yang dianggap penting, media massa, institusi pendidikan dan agama, faktor emosi dalam diri.

\section{METODE PENELITIAN}

Penelitian ini menggunakan metode kuantitatif dengan desain Ex-post-facto. Variabel-Variabel Penelitiannya adalah

Tanggapan pada Zakat/Jizyah Sebagai sumber APBN dan Sikap membayar zakat/jizyah

Lokasi Penelitiannya yaitu dilaksanakan di Kota Madiun, Propinsi Jawa Timur. Kota Madiun terdiri dari tiga Kecamatan yaitu Kecamatan Kartoharjo, Kecamatan Taman dan Kecamatan Mangunharjo. Masing-masing Kecamatan terdiri dari sembilan Kelurahan. Jumlah seluruh Kelurahan ada dua puluh tujuh. Kelurahan Pilangbango terpilih sebagai sampel Kecamatan Kartoharjo melalui undian, dan terdiri 1431 Kepala Keluarga (10\% darinya diberi angket). Kelurahan Manisrejo terpilih sebagai sampel Kecamatan Taman melalui undian dan terdiri 3000 Kepala Keluarga (10\% darinya diberi angket). Kelurahan Patihan terpilih sebagai sampel Kecamatan Mangunharjo melalui undian dan terdiri dari 1597 Kepala Keluarga (10\% darinya diberi angket). Pekerjaan warga ada yang pengusaha, pedagang, pegawai swasta, pegawai negeri dari berbagai instansi.

Teknik Pengumpulan Data dan Instrumen Penelitiannya adalah Dokumentasi dan Angket.

\section{HASIL DAN PEMBAHASAN}

Hasil penelitian membuktikan bahwa Hipotesa nihil diterima karena $t_{0}(0,059)$ lebih kecil dari $\mathrm{t}_{\mathrm{t}}(2,59)$. Hal ini menunjukkan bahwa tanggapan seseorang pada zakat/jizyah sebagai sumber APBN/APBD bergaris lurus atau tidak ada perbedaan dengan sikap membayar zakat/jizyah. 
Responden dalam kelas interval 73-81 menggambarkan pemahaman warga tentang fungsi zakat/jizyah sangat baik demikian sikap membayar zakat/jizyah

Tanggapan warga Kota Madiun tentang Zakat/Jizyah sebagai sumber APBN/APBD bergaris lurus dengan sikap membayar zakat/jizyah. Responden dalam kelas interval 64-72 menggambarkan pemahaman warga tentang fungsi dan sikap membayar zakat/jizyah baik walau ada perbedaan antara tanggapan dengan sikap tapi tidak signifikan, tanggapan selisih lebih sedikit tinggi (pemahaman tentang zakat/jizyah lebih baik) dari sikap membayar zakat/ jizyah.

Tanggapan warga Kota Madiun tentang Zakat/Jizyah sebagai sumber APBN/APBD bergaris lurus dengan sikap membayar zakat/jizyah. Responden dalam kelas interval 56-63 menggambarkan pemahaman warga tentang fungsi zakat/jizyah cukup demikian sikap membayar zakat/ jizyah walau ada perbedaan antara tanggapan dengan sikap tapi tidak signifikan, tanggapan selisih lebih sedikit rendah (pemahaman tentang zakat/jizyah cukup) dari sikap membayar zakat/jizyah. Responden dalam kelas interval 55-63 ini dapat dikatakan bahwa tanggapan pada zakat/jizyah sama cukup dengan sikap membayar zakat/jizyah.

Tanggapan warga Kota Madiun tentang Zakat/Jizyah sebagai sumber APBN/APBD bergaris lurus dengan sikap membayar zakat/jizyah. Responden pada kelas interval 46-54 menggambarkan pemahaman warga tentang fungsi zakat/jizyah kurang baik demikian sikap membayar zakat/jizyah walau ada perbedaan antara tanggapan dengan sikap tapi tidak signifikan, tanggapan selisih lebih sedikit rendah (pemahaman tentang zakat/jizyah kurang baik) dari sikap membayar zakat/jizyah. Tanggapan warga Kota Madiun tentang Zakat/Jizyah sebagai sumber APBN/APBD bergaris lurus dengan sikap membayar zakat/jizyah. Responden pada kelas interval 37-45 menggambarkan pemahaman warga tentang fungsi zakat/jizyah sangat rendah demikian sikap membayar zakat/jizyah walau ada perbedaan antara tanggapan dengan sikap tapi tidak signifikan, tanggapan selisih lebih tinggi dari sikap membayar zakat/ jizyah.

Tanggapan warga Kota Madiun tentang Zakat/Jizyah sebagai sumber APBN/APBD bergaris lurus dengan sikap membayar zakat/jizyah. Diagram pada kelas interval 28-36 menggambarkan pemahaman warga tentang fungsi zakat/jizyah sangat rendah demikian sikap membayar zakat/jizyah.

Tanggapan warga Kota Madiun tentang Zakat/Jizyah sebagai sumber APBN/APBD bergaris lurus dengan sikap membayar zakat/jizyah. Responden pada kelas interval 19-27 menggambarkan pemahaman warga tentang fungsi zakat/jizyah sangat amat rendah demikian sikap membayar 
zakat/jizyah walau ada perbedaan antara tanggapan dengan sikap tapi tidak signifikan, tanggapan selisih lebih sedikit rendah dari sikap membayar zakat/jizyah. Kelas interval ini dapat dikatakan bahwa tanggapan pada zakat/jizyah sama sangat amat rendahnya dengan sikap membayar zakat.

5. Kesimpulan

Simpulan

Hasil penelitian tentang Tanggapan Warga Kota Madiun Pada Zakat/Jizyah Sebagai Sumber APBN/APBD Terhadap Sikap Membayar Zakat dapat disimpulkan sebagai berikut:

a. Tanggapan warga Kota Madiun sama dengan Sikap mereka membayar zakat.

b. Sebagaian Tanggapan warga Kota Madiun sama tingginya dan sama baiknya dengan sikap mereka membayar zakat, hal ini ditunjukan pada kelas interval 73-81; 64-72; 56-63.

c. Sebagaian lainnya, Tanggapan Warga Kota Madiun berbanding lurus dan sangat rendah dengan sikap mereka membayar zakat, hal ini ditunjukan pada kelas interval 46-55;. 37-45; 28-36; 19-27.

Saran

Berdasarkan hasil penelitian, analisa data dan pembahasan maka dapat dikemukakan saran sebagai berikut:

a. Ulil 'Amri (Legeslatif, Eksekutif dan Yudikatif)

Sebagaian warga Kota Madiun memiliki tanggapan pada zakat/jizyah sebagai sumber APBN/APBD sama cukup dan baik dengan sikap mereka membayar zakat/jizyah. Hal ini sebagai modal untuk mempersiapkan undang-undang mengenai zakat/jizyah sebagai sumber APBN/APBD karena zakat adalah bentuk peran warga muslim untuk memberikan dana untuk mendanai pengelolan negara, demikian jizyah yang wajib dibayar oleh non Islam.

Sebagaian lain Warga Kota Madiun memiliki tanggapan pada zakat/jizyah sebagai sumber APBN/APBD sama rendah dan sangat rendah dengan sikap mereka membayar zakat/jizyah. Hal ini tugas ulil 'amri dan ustad, ustadah untuk memberikan pemahaman sehingga mereka faham akan fungsi zakat/jizyah dan bersikap berbanding lurus dengan sikap mereka membayar zakat/jizyah.

b. Peneliti Lain

Keterbatasan waktu dan tenaga maka disarankan bagi peneliti lain untuk melaksanakan penelitian yang sama tapi lokasi yang berbeda untuk 
menambah bahan pertimbangan bagi pembuat peraturan atau undangundang.

\section{DAFTAR PUSTAKA}

Abu Ahmadi. 2009. Psikologi Sosial. Jakarta: Rineka Cipta

Abdullah Muhammad bin Yusuf, Abu Hayyan. Tafsir Bahrul-Muhith.

Abul-Hasan Ali bin Abi Bakar, al-Marghinani, Al-Hidayah.

Abu Muhammad Abdul Malik bin Muhammad bin Hisyam, Siratun-Nabawiyyah.

Al Faridy, Hasan Rifa'i, Drs., 1996. Panduan Zakat Praktis. Dompet Dhuafa Republia.

Ali Yafie. 1994. Menggagas Fiqh Sosial. Bandung : Mizan.

Badrudin Mahmud bin Ahmad, Al-'Aini, 'Umdatul-Qari, Hanafi.

Baiquni dkk. 1996. Kamus Istilah Agama Islam Lengkap. Surabaya: Indah.

Bisnis. Alokasi Belanja Negara Tahun 2014 Rp 1.816,7 Triliun. Jum'at, 16 Agustus 2013 | 16:18 WIB, Tempo Co.

Departemen Agama. 1989. Qur'an dan Terjemahannya. Semarang : CV. Al Waad.

Agama.

--------- ---. 1994. Ensiklopedi Islam : Terbitan PT. Ichtiar Baru Van Hoeve Jakarta. Cetakan ke II : juz 5.

Hafizh u Abbu Abdillah Muhammad bin Ismail, al-Bukhari, Sahih Bukhari.

Ibnu Hajar; Nazhatun Nazhar Syarh Nukhbtaul-Fikr.

Imam Abu Ja'far Muhammad bin Jarir Thabari,Jami'ul Bayan fi Tafsiril-Qur'an.

Imam Abu H; Husain Muslim bin Hajjaj, Sahih Muslim.

Imam Ahmad bin Hambal, Musnad

Imam Hafizh Abu Isa Muhammad bin Jami'at-Tirmidhi.

Irwanto dkk, 2002, Psikologi Umum Buku Panduan Mahasiswa, Jakarta: P.T. Prenhalindo.

Khallaf, 'Abd al-Wahhab. 1978. 'Ilm Ushul al-Fiqh. Al-Qahirah: Dar al-'Ilm li alThiba'ah wa al-Nasyr wa al-Tawzi' .

Muhammad bin Sa'ad, Kitabut-Tabaqat al-Kubra.

Pedoman Zakat. 2001. Artikel Majalah Suara Hidayatullah. Edisi Khusus 07/XIV/November.

Robert S Feldmen. 2012. Pengantar Psikologi. Jakarta: Salemba.

Sarlito, W. Sarito. 2009. Pengantar Psikologi Umum. Jakarta: Rajawali Pers.

Shaleh, Abdul Rahman. 2009. Psikologi Suatu Pengantar dalam Perspektif Islam. Jakarta: Kencana

Sugiyono. 2013. Metode Penelitian Kombinasi (Mixed Methods). Bandung: ALFABETA.

Sumber URL : Pembahasan penting-penting seputar zakat, http://nasihatonline.wordpress.com/2010/08/27/

Suratno, S.Ag., MAP.Ketua BAZNAS Kab. Kepl. SITARO.

Syah Waliyullah, Muhaddats Dahlewi, Hijjatullah al-Balighah.

Syeikh Waliyyuddin Muhammad bin Abdillah, Misykatul Mashabih. 
Yusuf Qardawi. 1997. Kiat Sukses Mengelola Zakat. Terjemahan Asmuni Solihan Zamakhayari. Jakarta : Media Dakwah.

Yusuf Qardhawi. 1999. Hukum Zakat. Bogor : Litera Antar Nusa. 